\title{
An examination of the observed placebo effect associated with the treatment of low back pain - a systematic review
}

\author{
Aaron A Puhl MSc*, Christine J Reinhart PhD*, Elisabeth R Rok BSc*, H Stephen Injeyan PhD DC
}

\begin{abstract}
AA Puhl, CJ Reinhart, ER Rok, HS Injeyan. An examination of the observed placebo effect associated with the treatment of low back pain - a systematic review. Pain Res Manage 2011;16(1):4552.
\end{abstract}

OBJECTIVE: To determine whether the nonspecific effects that occur following the use of sham interventions to treat nonspecific low back pain (LBP) are large enough to be considered clinically meaningful.

DESIGN: Electronic databases were searched systematically for randomized placebo-controlled trials of interventions for LBP that used sham ultrasound, sham laser or sham drug therapy as the placebo control. Study selection was accomplished via independent evaluation of scientific admissibility by three reviewers and final decisions of inclusion were based on consensus.

RESULTS: None of the studies using sham ultrasound as the placebo control in the treatment of LBP were acceptable for inclusion. Twelve studies were included in the present evaluation of the placebo effect - eight trials that met the strict inclusion criteria for best evidence (three using sham laser placebo and five using sham medication placebo) and four sham medication studies that 'just missed' the inclusion criteria for best evidence. Although the evidence from studies using sham laser was inconclusive, the present review did find a clinically meaningful change in LBP scores following the use of sham oral medications.

CONCLUSIONS: The present best-evidence review found a clinically meaningful change in pain scores following the use of sham oral medications for the treatment of nonspecific LBP. This finding suggests that further clinical research is warranted to identify which patient subgroups could benefit most from such treatment and to distinguish the true contribution of the placebo effect from other nonspecific effects.

Key Words: Low back pain; Placebo; Systematic review; Therapy; Treatment

\section{L'examen de l'effet placebo observé associé au traitement des douleurs lombaires : une analyse systématique}

OBJECTIF : Déterminer si les effets non spécifiques qui se produisent après l'utilisation d'interventions placebo pour traiter des douleurs lombaires non spécifiques (DLNS) sont suffisants pour être considérés comme significatifs sur le plan clinique.

MÉTHODOLOGIE : Les chercheurs ont effectué des recherches systématiques dans les bases de données électroniques afin de trouver des essais aléatoires contrôlés contre placebo sur des interventions de DLNS qui faisaient appel à des échographies placebo, au laser placebo et à des médicaments placebo comme contrôles. La sélection des études s'est effectuée au moyen d'une évaluation indépendante de l'admissibilité scientifique par trois réviseurs, et les décisions définitives d'inclusion étaient consensuelles.

RÉSULTATS : Aucune des études faisant appel à des échographies placebo comme contrôles dans le traitement des DLNS n'était acceptable à l'inclusion. Douze études ont été incluses dans la présente évaluation de l'effet placebo, soit huit études qui respectaient les critères d'inclusion rigoureux de meilleures données probantes (trois faisant appel à un laser placebo et cinq, à des médicaments placebo) et quatre études sur des médicaments placebo qui " avaient été tout juste exclues » des critères d'inclusion de meilleures données probantes. Même si les données probantes tirées d'études faisant appel au laser placebo n'étaient pas concluantes, la présente analyse a découvert un changement significatif sur le plan clinique des indices de DLNS après l'utilisation de médicaments placebo par voie orale.

CONCLUSIONS : La présente analyse des meilleures données probantes a permis de découvrir un changement significatif des indices de douleur sur le plan clinique après l'utilisation de médicaments placebo par voie orale pour traiter des DLNS non spécifiques. Cette observation indique que d'autres recherches cliniques s'imposent pour déterminer quels sousgroupes de patients pourraient profiter le plus de ce traitement et pour distinguer le véritable apport de l'effet placebo de ses effets non spécifiques.

continuous subjective outcomes. Various counter-arguments have since been put forward to explain the negative results reported by Hrobjartsson and Gotzsche (4), including their use of meta-analysis to attempt to examine a complex phenomenon such as placebo. It has been suggested that meta-analyses are too mechanistic and are driven more by concerns of reproducibility rather than contributing to an understanding of the phenomenon of interest (5). More specifically, meta-analyses have the potential to dilute therapeutic outcomes, even possibly deem them insignificant, when heterogeneous therapies, diseases and outcomes are compiled in a single analysis (6). Quantifying the clinical efficacy of placebo is further complicated if one considers the suggestion by Moerman and Jonas (1) that the placebo effect is a "meaning response", in which the placebo treatment is only effective if it has meaning to the patient. Thus, it is possible that subgroups within a patient population can respond differently to the same placebo intervention, dependent on whether they perceive it to be of

cebos had no significant effects on objective or binary outcomes, and only small benefits with regard to the treatment of pain and

*These authors contributed equally to this work

Canadian Memorial Chiropractic College, Toronto, Ontario

Correspondence: Dr H Stephen Injeyan, Canadian Memorial Chiropractic College, 6100 Leslie Street, Toronto, Ontario M2H 3J1.

Telephone 416-482-2340 ext 172, fax 416-488-0470, e-mail sinjeyan@cmcc.ca 
great or little therapeutic value. Finally, discriminating the contribution of the true placebo effect from nonspecific effects such as natural recovery and regression to the mean requires studies comparing placebo interventions with no-treatment controls, a methodology that raises ethical concerns. Despite the controversy surrounding the clinical efficacy of the placebo effect and the difficulty in studying this phenomenon, it has been shown that approximately one-half of internists and rheumatologists are prescribing placebo treatments of some form on a regular basis, and that most physicians believe the practice to be ethically permissible (7).

Low back pain (LBP) is a common condition, with a lifetime prevalence as high as $84 \%$ (8) - second only to upper respiratory problems as a symptom-related reason for visits to a physician in the United States (9). LBP can be defined as acute, subacute or chronic, and the precise duration of each is heterogeneously defined throughout the literature. It has often been stated that the natural history of acute back pain has a favourable resolution, in part because early studies such as that by Coste et al (10) reported that $90 \%$ of LBP patients seen within three days of onset recovered within two weeks. However, investigations since then have suggested that it may be more accurate to estimate that $25 \%$ to $30 \%$ of patients recover in one week, and $60 \%$ of patients recover in seven weeks $(11,12)$. A very recent study by Henschke et al (13) found that nearly one-third of patients did not recover from the presenting episode within a year. In line with these individual findings, a recent systematic review (14) also indicated a much less favourable prognosis than has commonly been reported. For patients whose pain continues on to chronicity, back pain is rarely selflimiting; fewer than $10 \%$ of patients with long-lasting back pain at baseline reported no pain five years later (15).

Clinicians treating LBP may choose from a wide range of options including exercise therapy, medications, manipulation, acupuncture, electrical modalities and cognitive-behavioural interventions. Currently, it appears that the ideal treatment for LBP is a multidisciplinary intervention with a stepwise approach (16) and, indeed, studies examining the effectiveness of these treatments are becoming numerous. In contrast, placebo treatments, although used on occasion in clinical practice (7), have not been thoroughly investigated with studies designed to specifically assess the placebo effect in the treatment of LBP. This is particularly surprising when considering the known contribution of placebo to the general effectiveness of analgesic pharmaceuticals $(17,18)$.

In an attempt to better understand how nonspecific effects might contribute to the treatment of nonspecific LBP and to determine whether studies designed specifically to assess placebo treatment of LBP are warranted, a best-evidence model was used in the present systematic review of randomized, controlled clinical trials. The goal of the review was threefold - to first determine whether one treatment results in a more profound change after a sham intervention than another; second, to determine whether any of those observed effects are large enough to be considered clinically meaningful; and finally, to assess whether studies designed specifically to assess the contribution of the true placebo effect, by comparison with no-treatment control groups, are warranted.

\section{Definitions of placebo and LBP}

\section{METHODS}

In clinical trials, placebos are generally control treatments that are indistinguishable from the study treatments but that lack their specific activity. The most obvious way to blind patients to their allocation is to provide one group with a placebo intervention that is structurally equivalent to the experimental intervention. The intention of the present review was to examine multiple forms of sham treatment, with the requirement that subjects be completely blinded to the fact that their treatment was functionally inert. With this in mind, sham ultrasound, sham cold laser and sham oral drug therapy were the only treatments agreed on for inclusion in the present review (see Discussion). Therefore, the examined studies were randomized clinical control trials investigating treatments for nonspecific LBP that was acute (ie, pain present for less than $48 \mathrm{~h}$ ), subacute (ie, pain present between four weeks and 12 weeks) or chronic (ie, pain present for longer than three months) using sham laser, ultrasound or drug therapy as a placebo control. Nonspecific LBP was defined as pain below the 12 th costal margin and above the inferior gluteal folds, without pain radiating below the knee for which specific etiologies such as infection, tumour, osteoporosis, fracture, structural deformity, inflammatory disorder, radicular syndrome or cauda equina syndrome, and other relevant pathological entities had been excluded.

\section{Search strategy}

A systematic search was conducted from January 1975 to December 2008 in MEDLINE (via PubMed), CINAHL, AMED (alternative medicine), Nursing \& Allied Health Collection: Comprehensive, and Alt HealthWatch using the strategy recommended by the Cochrane Back Review Group (19). The search was limited to English-language or English language-translated human studies, and was repeated with synonyms of "placebo" and "low back pain" and "randomized clinical trial" and "laser therapy" or "ultrasound therapy" or "drug therapy". Further searches were performed with synonyms of "detuned ultrasound", "inactive laser" or "inert drug". Separate searches were conducted for each of the three therapies of interest. Selected literature reviews and bibliographies were also examined to identify additional studies.

\section{Study selection}

Three reviewers (AP, CR and ER) were each assigned one or two database(s) in which to apply the search strategy and locate potentially relevant studies. Titles and abstracts were examined initially to identify randomized placebo-controlled trials that used sham laser, ultrasound or drugs to evaluate the efficacy of an intervention for LBP, in which outcomes had been reported in terms of pain or disability. Studies obtained from independent literature searches meeting the inclusion criteria were pooled, and full texts were obtained.

The selected studies were subjected to a process of critical review similar to that of the Task Force on Neck Pain (20), in which standardized forms were used to focus reviewers on the presence or absence of important methodological issues. The critical review forms prompted reviewers to focus on issues such as study design, study population, study conduct, participation rates, follow-up rates and measurement issues. These key quality measures were consistent with the CONsolidated Standards of Reporting Trials (CONSORT) statement (21) for ensuring the quality of randomized controlled trials. All four authors independently read each article, and three (AP, CR and ER) critically reviewed them independently. The entire team then met to determine the articles to be included in the present review. Studies were not assigned a quantitative score for judging scientific acceptability. Instead, the team discussed the internal validity of each study and used consensus to decide whether a study was scientifically admissible (22). An inadmissible study was one in which the methodological weaknesses were judged to potentially lead to bias, such that the study's validity was significantly threatened and its results could not be accepted with reasonable confidence. Because this synthesis was concerned with the outcomes of the group receiving a placebo intervention, emphasis was placed on judging methodology that could bias this group's outcomes.

To be included in the present systematic review, studies were required to meet the following criteria: complete description of the LBP being treated to ensure it conformed to the study definition of LBP; appropriate description of inclusion/exclusion criteria; blinding of the patients, the person administering the therapy and/or the person assessing outcomes; minimization of selection bias; absence of co-interventions; clear justification of sample size; clear explanation of any subject withdrawals; and clear indication of whether intention-to-treat analysis was performed (eg, final analysis was based on outcomes from every subject who provided data at baseline and at least one postrandomization observation time). 


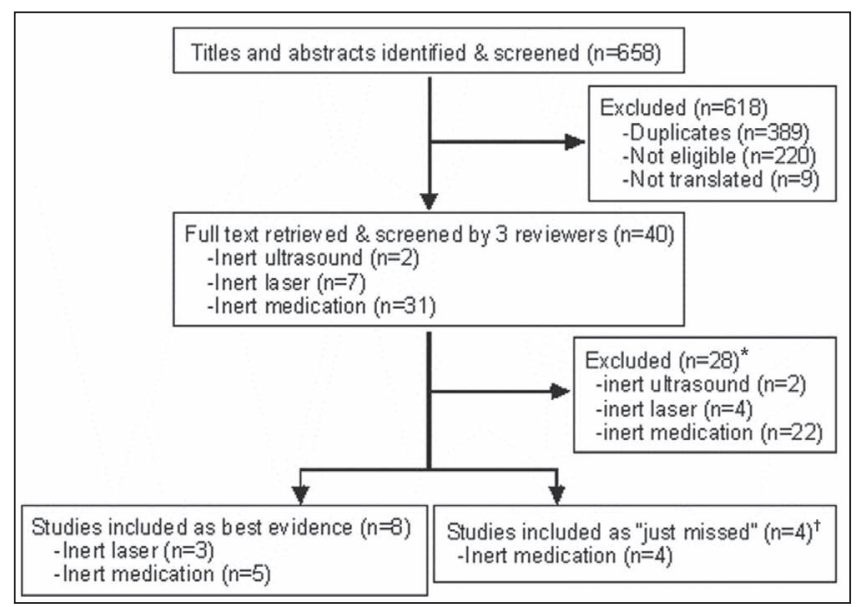

Figure 1) Search and selection of studies. *See Table 1 for reasons of exclusion; 'See text for rationale

\section{Data synthesis}

Data for the best-evidence synthesis consisted of studies that fulfilled the selection criteria and were, thus, judged to have adequate internal validity. The numerical data dealing with pain, disability or overall efficacy from the studies judged to be scientifically admissible were abstracted into tables by a single author (AP). For studies in which data were only provided in graphic format, an overlying grid was used to generate specific values. A meta-analysis of all studies or subgroups within the selected studies was not performed due to clinical and experimental heterogeneity. Study outcomes were individually examined for clinical relevance, in which a $30 \%$ or greater change from baseline was considered clinically meaningful, as previously established by consensus on clinical interpretation (23). In addition, studies were qualitatively analyzed according to the consistency of their evidence.

\section{RESULTS}

Literature search and quality appraisal

The initial search identified 658 titles/abstracts - 31 using sham ultrasound, 39 using sham laser and 588 using sham medication (Figure 1). Following the preliminary screening of these titles/abstracts for eligible studies, 40 nonduplicate studies were selected for further examination - two studies using sham ultrasound as a placebo, seven studies using sham laser as a placebo and 31 studies using sham oral medication as a placebo. Of the 40 studies selected for critical review, only eight were accepted as best evidence - three with sham laser placebo (24-26) and five with sham oral medication placebo (27-31). Although many of the remaining 32 studies contained multiple methodological weaknesses that resulted in their exclusion (Table 1), four studies using sham oral medication as a placebo were judged to have only one common methodological weakness (ie, failed to eliminate all possible confounding treatments). Because these studies were otherwise judged to have sufficient scientific validity, they were included in the final analysis as studies that 'just missed' being included as best evidence $(32-35)$. No studies that used sham ultrasound for a placebo control in the treatment of LBP were acceptable for inclusion in the present review.

\section{Qualitative analysis of best evidence}

The characteristics and outcomes of the eight selected studies (24-31) are summarized in Tables 2 and 3. These studies primarily used subjective continuous outcome measures for both pain (eg, visual analogue scale [VAS], McGill Pain Questionnaire and Modified Brief Pain Inventory) and disability (eg, Roland Morris Disability Questionnaire and Oswestry Disability Questionnaire). In addition, several studies used discrete outcome measures, such as patient and/or physician
TABLE 1

Reasons for exclusion of studies $(n=32)$

\begin{tabular}{ll}
\hline Reason & Reference \\
\hline $\begin{array}{l}\text { Inclusion/exclusion criteria for low back pain } \\
\text { examined outside the scope of this synthesis }\end{array}$ & $(46-56)$ \\
$\quad$ eg, neurological deficits) & \\
$\begin{array}{l}\text { Multiple complaints examined (eg, neck and back) } \\
\text { Multiple sham treatments or concurrent active }\end{array}$ & $(49,57,58)$ \\
$\quad \begin{array}{l}\text { therapy administered to placebo group } \\
\text { Insufficient description of inclusion/exclusion } \\
\text { criteria }\end{array}$ & $(57,58,61-66)$
\end{tabular}

Possible confounding treatments allowed to continue or their exclusion not described (eg, chiropractic, acupuncture or massage therapy)

Lack of or inadequately described blinding Weakness in blinding methodology (run-in phase)

Compliance or reasons for noncompliance inadequately described

Unclear if final outcomes based on intention-to-treat analysis

Comorbidities not excluded

Small sample size

(32-35,48,62,64,67-70)

Other

$(64,68,71)$

$(56,66,67,69,70)$

$(53,57,58,72)$

$(61,73)$

$(58,59,68)$

Note: Most studies were found to have several weaknesses and, as such, are included in the table more than once

global assessment, including four- or five-point scales with word descriptors (eg, $0=$ no relief, $1=$ a little relief, $2=$ some relief, $3=$ a lot of relief and $4=$ complete relief). The conclusions made in the present review were based primarily on the data from established continuous measures. For comparison purposes, discrete measures have also been presented in the study summary tables where applicable.

Sham laser: All three clinical trials using sham laser as a placebo intervention included subjects whose LBP could be considered chronic. A summary of the results of these studies is given in Table 2. Two studies $(25,26)$ found no improvement of pain or disability from baseline after four weeks of sham laser intervention. However, the use of overall averages for reporting data in these studies may have concealed any minor benefits incurred by a small subgroup of their subject populations. One study (24) found a clinically meaningful improvement of pain in $69.7 \%$ of subjects in the placebo group following two weeks of sham laser intervention. Unfortunately, failure to consider data from $25 \%$ of patients who withdrew early from this study's placebo group (due to lack of efficacy) certainly exaggerated the number of positive outcomes. Nevertheless, inclusion of the $25 \%$ of subjects who withdrew resulted in $55 \%$ of subjects experiencing a clinically relevant benefit from sham laser therapy.

Sham medication: Five studies using sham medication as a placebo intervention were judged to have sufficient scientific validity to be accepted as best evidence (Table 3$)$ - two trials in acute $\operatorname{LBP}(27,28)$, one trial in subacute LBP $(31)$ and two trials in chronic LBP $(29,30)$. Both of the studies that included subjects with acute LBP $(27,28)$ found a clinically meaningful improvement in average pain scores following three days of treatment. Only one of these studies examined disability (28), and although the authors found no significant improvement after three days, a meaningful improvement in average disability scores was observed after eight days. The single study that included subjects with subacute LBP (31) found clinically significant changes in average pain and disability scores after 30 days of treatment. However, at seven days of treatment, improvements in disability were not clinically significant, nor were pain outcomes reported at this time. Two studies included subjects with chronic LBP $(29,30)$. Coats et al (30) found significant improvements in average pain scores after two and four weeks of treatment. Moreover, $41 \%$ of subjects in this study reported a greater than $50 \%$ improvement in pain after only one 
TABLE 2

Characteristics and outcomes of best-evidence trials that used a sham laser placebo

\begin{tabular}{|c|c|c|c|}
\hline Author, year (reference) & Preyde, 2000 (26) & Basford et al, 1999 (25) & Soriano and Rios, 1998 (24) \\
\hline $\begin{array}{l}\text { Symptom duration at baseline, } \\
\text { inclusion criteria (mean) }\end{array}$ & $\begin{array}{l}>1 \text { week, but }<8 \text { months } \\
\text { (13.3 weeks) }\end{array}$ & >30 days (12.8 months) & >3 months (NR) \\
\hline $\begin{array}{l}\text { Placebo group, } \mathrm{n} \text { allocated } \\
\text { ( } \mathrm{n} \text { completed) }\end{array}$ & $27(26)$ & $29(29)$ & $42(33)$ \\
\hline Reasons for noncompliance & NR & NA & $\begin{array}{l}3 \text { abandoned treatment, } 6 \text { withdrawn } \\
\text { for NSAID use }\end{array}$ \\
\hline Age, years, mean \pm SD & $41.9 \pm 16.6$ & $48.2 \pm N R$ & $64.3 \pm N R$ \\
\hline Characteristics of placebo treatment & $\begin{array}{l}\text { Sham laser treatment } 6 \text { times over } \\
1 \text { month }\end{array}$ & $\begin{array}{l}\text { Sham laser treatment } 3 \text { times per week for } \\
4 \text { weeks }\end{array}$ & $\begin{array}{l}\text { Sham laser treatment } 5 \text { times per } \\
\text { week for } 2 \text { weeks }\end{array}$ \\
\hline Outcome measurement & $\begin{array}{l}0 \text { (baseline), } 4 \text { weeks and } 8 \text { weeks } \\
\text { (follow up) }\end{array}$ & $\begin{array}{l}0 \text { (baseline), } 2 \text { weeks, } 4 \text { weeks and } 8 \text { weeks } \\
\text { (follow up) }\end{array}$ & $\begin{array}{l}0 \text { (baseline), } 2 \text { weeks and } 26 \text { weeks } \\
\text { (follow up) }\end{array}$ \\
\hline Pain outcomes & $\begin{array}{l}\text { MPQ PPI score*: 2.0, } 1.7 \text { and 1.8; } \\
\text { MPQ PRI score*: 11.1, 8.3 and } \\
7.7\end{array}$ & $\begin{array}{l}\text { VAS score* for maximum pain on palpation: } \\
27.1 \mathrm{~mm}, 34.1 \mathrm{~mm}, 25.7 \mathrm{~mm} \text { and } 21.9 \mathrm{~mm} \text {; } \\
\text { VAS score* for maximum pain in previous } 24 \mathrm{~h} \text { : } \\
37.4 \mathrm{~mm}, 38.6 \mathrm{~mm}, 32.8 \mathrm{~mm} \text { and } 35.1 \mathrm{~mm}\end{array}$ & $\begin{array}{l}\text { Subjects with } 60-100 \% \text { improvement } \\
\text { on VAS: NA, } \mathbf{3 6 . 4 \%} \text { and } \mathbf{1 0 . 9 \%} \text {; } \\
\text { subjects with } 30-59 \% \text { improvement } \\
\text { on VAS: NA, } \mathbf{3 3 . 3} \% \text { and NR }\end{array}$ \\
\hline Disability outcomes & $\begin{array}{l}\text { Roland Morris Disability } \\
\text { Questionnaire score*: } 7.2,6.9 \\
\text { and 6.5; flexion ROM*: } 5.5 \mathrm{~cm} \text {, } \\
6.0 \mathrm{~cm} \text { and } 5.5 \mathrm{~cm}\end{array}$ & $\begin{array}{l}\text { Oswestry Disability Index score*: 25, 22.9, } 22.6 \\
\text { and } 22.9 \text {; flexion } \mathrm{ROM}^{*}: 14.2 \mathrm{~cm}, 14.4 \mathrm{~cm} \text {, } \\
14.0 \mathrm{~cm} \text { and } 14.2 \mathrm{~cm}\end{array}$ & All NR \\
\hline
\end{tabular}

*Values represent mean scores. Bolded values represent a 30\% or greater change from baseline. MPQ McGill Pain Questionnaire; NA Not applicable; NR Not reported; NSAID Nonsteroidal anti-inflammatory drug; PPI Present Pain Intensity; PRI Pain Rating Index; ROM Range of motion; VAS Visual analogue scale

\section{TABLE 3}

Characteristics and outcomes of best-evidence trials that used a sham oral medication placebo

\begin{tabular}{|c|c|c|c|c|c|}
\hline Author, year (reference) & Amlie et al, 1987 (27) & Dreiser et al, 2003 (28) & Bannwarth et al, 2005 (31) & Coats et al, 2004 (30) & Ruoff et al, 2003 (29) \\
\hline $\begin{array}{l}\text { Symptom duration at } \\
\text { baseline, inclusion } \\
\text { criteria (mean) }\end{array}$ & $\begin{array}{l}<48 \mathrm{~h} \text { and no previous } \\
\text { episodes for } 3 \text { months } \\
(25.6 \mathrm{~h})\end{array}$ & $\begin{array}{l}<48 \mathrm{~h} \text { and no previous } \\
\text { episodes for } 3 \text { months } \\
(60 \% \text { had onset within } \\
24 \mathrm{~h})\end{array}$ & $\begin{array}{l}>4 \text { week but <12 weeks } \\
\text { ( } 7.1 \text { weeks) }\end{array}$ & $\begin{array}{l}\text { >3 months requiring regular } \\
\text { analgesic medication use } \\
\text { (10.9 years) }\end{array}$ & $\begin{array}{l}\text { >3 months requiring daily } \\
\text { analgesic medication } \\
(\mathrm{NR})\end{array}$ \\
\hline $\begin{array}{l}\text { Placebo group, } \\
\text { n allocated } \\
\text { ( } \mathrm{n} \text { completed) }\end{array}$ & $142(132)$ & $126(118)$ & $80(80)$ & $145(115)^{*}$ & $157(74)^{\star}$ \\
\hline $\begin{array}{l}\text { Reasons for } \\
\text { noncompliance }\end{array}$ & $\begin{array}{l}10 \text { withdrawn for } \\
\text { protocol violations }\end{array}$ & $\begin{array}{l}8 \text { withdrew due to } \\
\text { adverse reactions }\end{array}$ & NA & $\begin{array}{l}16 \text { withdrew due to lack of } \\
\text { efficacy; } 14 \text { due to protocol } \\
\text { violation or other }\end{array}$ & $\begin{array}{l}59 \text { withdrew due to lack of } \\
\text { efficacy; } 24 \text { due to } \\
\text { protocol violation or other }\end{array}$ \\
\hline Age, years, mean \pm SD & $38.1 \pm N R$ & $41.0 \pm 11.3$ & $41.0 \pm 9.8$ & $48.7 \pm 12.6$ & $54.1 \pm 12.0$ \\
\hline $\begin{array}{l}\text { Characteristics of } \\
\text { placebo treatment }\end{array}$ & $\begin{array}{l}1 \text { tablet per day for } \\
7 \text { days }\end{array}$ & $\begin{array}{l}\text { 1-2 tablets every } 4-6 \mathrm{~h} \\
\text { for } 7 \text { days }\end{array}$ & $\begin{array}{l}1 \text { capsule per day for } \\
30 \text { days }\end{array}$ & 1 tablet per day for 4 weeks & $\begin{array}{l}\text { 4-8 tablets per day for up } \\
\text { to } 91 \text { days }\end{array}$ \\
\hline Outcome measurement & $\begin{array}{l}0 \text { (baseline), } 3 \text { days } \\
\text { and } 7 \text { days }\end{array}$ & $\begin{array}{l}0 \text { (baseline), } 3 \text { days } \\
\text { and } 8 \text { days }\end{array}$ & $\begin{array}{l}0 \text { (baseline), } 7 \text { days and } \\
30 \text { days }\end{array}$ & $\begin{array}{l}0 \text { (baseline) }^{\dagger}, 1 \text { week, } \\
2 \text { weeks and } 4 \text { weeks; or } \\
\text { time of withdrawal* }\end{array}$ & $\begin{array}{l}0 \text { (baseline) }^{\dagger} \text { and } 91 \text { days; } \\
\text { or time of withdrawal* }\end{array}$ \\
\hline Pain outcomes & $\begin{array}{l}\text { Improvement on VAS }{ }^{\ddagger} \\
\text { for sitting: NA, 38\% } \\
\text { and } 70 \% \text {; lying: NA, } \\
42 \% \text { and } 73 \% \text {; } \\
\text { standing: NA, } 37 \% \text { and } \\
68 \% \text {; walking: NA, } 42 \% \\
\text { and } 72 \%\end{array}$ & $\begin{array}{l}\text { VAS scores }{ }^{\ddagger}: 71.4 \mathrm{~mm} \text {, } \\
\mathbf{4 6 . 0} \mathrm{mm} \text { and } 33.9 \mathrm{~mm} \text {; } \\
\text { subjects rating pain } \\
\text { relief } \geq 2 \text { on patient } \\
\text { global assessment }{ }^{\ddagger \S} \text { : } \\
\text { NA, NR and } 58 \%\end{array}$ & 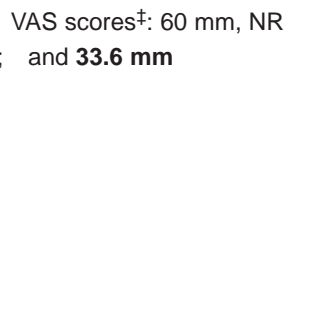 & $\begin{array}{l}\text { VAS scores }{ }^{\ddagger}: 75 \mathrm{~mm}^{\dagger} \text {, } \\
57 \mathrm{~mm}, \mathbf{4 6} \mathrm{mm} \text { and } \\
\mathbf{4 4} \mathbf{~ m m} \text {; Modified Brief } \\
\text { Pain Inventory }{ }^{\ddagger} \\
\text { interference composite } \\
\text { scores: } 39^{\dagger}, \mathbf{2 8 ,} 23 \text { and 22; } \\
\text { subjects reporting >50\% } \\
\text { pain relief: NA, } \mathbf{4 1 \%}, \mathrm{NR} \\
\text { and } \mathbf{5 4 \%}\end{array}$ & $\begin{array}{l}\text { VAS }^{\ddagger} \text { scores of how much } \\
\text { pain in the previous } 48 \mathrm{~h} \text { : } \\
68.8 \mathrm{~mm}^{\dagger} \text { and } 52.3 \mathrm{~mm} \text {; } \\
\text { Short-Form McGill Pain } \\
\text { Questionnaire scores }{ }^{\ddagger} \text { : } \\
\text { 18.1 }{ }^{\dagger} \text { and } 13.3 \text {; subjects } \\
\text { reporting }>50 \% \text { pain relief: } \\
\text { NA and } 32.5 \% ;>30 \% \text { pain } \\
\text { relief: NA and } 39.5 \%\end{array}$ \\
\hline Disability outcomes & $\begin{array}{l}\text { Physicians' opinion }{ }^{\ddagger} \\
\text { of functional } \\
\text { improvement: NA, } 40 \% \\
\text { and } 70 \%\end{array}$ & $\begin{array}{l}\text { RMDQ scores }{ }^{\ddagger}: 13,9.3 \\
\text { and } 7.3\end{array}$ & $\begin{array}{l}\text { RMDQ scores }{ }^{\ddagger}: \text { 11, } 9.1 \\
\text { and } 6.1\end{array}$ & $\begin{array}{l}\text { RMDQ scores }{ }^{\ddagger}: 12.3^{\dagger}, 10.4 \text {, } \\
9.4 \text { and } 8.4\end{array}$ & $\begin{array}{l}\text { RMDQ scores }{ }^{\ddagger}: 14.2^{\dagger} \text { and } \\
11.6\end{array}$ \\
\hline Other outcomes & $\begin{array}{l}\text { Subjects requiring } \\
\text { rescue analgesic; NA, } \\
\text { NR and } 47 \%\end{array}$ & $\begin{array}{l}\text { Patient global } \\
\text { assessment of } \\
\text { medication } \\
\text { effectiveness }^{\mp \pi} \text { : NA, } \\
1.3 \text { and } 2\end{array}$ & $\begin{array}{l}\text { Physician and patient } \\
\text { global assessment - } \\
\% \text { strongly improved: NA, } \\
\text { NR, } 43.6 \% \text { and } 38.5 \%\end{array}$ & $\begin{array}{l}\text { Patient's assessment of } \\
\text { medication effectiveness - } \\
\% \text { good to excellent }{ }^{\ddagger \pi} \text { : NA, } \\
44 \% \text {, NR and } 52 \%\end{array}$ & $\begin{array}{l}\text { Physician and patient } \\
\text { overall assessment of } \\
\text { medication effectiveness - } \\
\% \text { good or very good }{ }^{\ddagger} \text { : } \\
\text { NA, } 37.9 \% \text { and } 35.6 \%\end{array}$ \\
\hline
\end{tabular}

Bolded values represent a $30 \%$ or greater change from baseline. ${ }^{*}$ Intention-to-treat analysis - outcomes were assessed at the final visit before withdrawal; ${ }^{\dagger}$ Baseline measurements were taken following a three-week medication washout phase; ${ }^{\ddagger}$ Values represent average scores; ${ }^{\S} \mathrm{Pain}$ relief was rated as $0=$ no relief, $1=$ a little relief, 2 = some relief, $3=$ a lot of relief and $4=$ complete relief; "Efficacy of medication was rated as $0=$ very poor, $1=$ poor, $2=$ good, $3=$ very good and $4=$ excellent. NA Not applicable; NR Not reported; RMDQ Roland Morris Disability Questionnaire; VAS Visual analogue scale 
TABLE 4

Characteristics and outcomes of trials that 'just missed' being included as best-evidence trials

\begin{tabular}{|c|c|c|c|c|}
\hline $\begin{array}{l}\text { Author, year } \\
\text { (reference) }\end{array}$ & Birbara et al, 2003 (32) & Katz et al, 2003 (33) & Pallay et al, 2004 (34) & Peloso et al, 2004 (35) \\
\hline $\begin{array}{l}\text { Symptom duration at } \\
\text { baseline - inclusion } \\
\text { criteria (mean) }\end{array}$ & $\begin{array}{l}>3 \text { months and at least } \\
30 \text { days requiring daily } \\
\text { analgesic medication } \\
\text { (10.7 years) }\end{array}$ & $\begin{array}{l}\text { >3 months requiring daily } \\
\text { analgesic medication } \\
\text { (12.6 years) }\end{array}$ & $\begin{array}{c}>3 \text { months and at least } 30 \text { days requiring } \\
\text { daily analgesic medication ( } 11.5 \text { years) }\end{array}$ & $\begin{array}{l}\text { >3 months requiring daily } \\
\text { analgesic medication } \\
\text { (12.6 years) }\end{array}$ \\
\hline $\begin{array}{l}\text { Placebo group, } \\
\text { n allocated } \\
\text { ( } \mathrm{n} \text { completed) }\end{array}$ & $109(65)^{\star}$ & $228(185)^{\star}$ & $110(77)^{\star}$ & $169(61)^{\star}$ \\
\hline $\begin{array}{l}\text { Reasons for } \\
\text { noncompliance }\end{array}$ & $\begin{array}{l}27 \text { withdrew due to lack of } \\
\text { efficacy; } 17 \text { due to protocol } \\
\text { violation or other }\end{array}$ & $\begin{array}{l}30 \text { withdrew due to lack of } \\
\text { efficacy; } 13 \text { due to adverse } \\
\text { reactions or other }\end{array}$ & $\begin{array}{l}17 \text { withdrew due to lack of efficacy; } \\
16 \text { due to protocol violation or other }\end{array}$ & $\begin{array}{l}82 \text { withdrew due to lack of } \\
\text { efficacy; } 13 \text { due to adverse } \\
\text { reactions and } 15 \text { due to } \\
\text { protocol violation or other }\end{array}$ \\
\hline $\begin{array}{l}\text { Age, years, mean } \pm \\
\text { SD }\end{array}$ & $51.0 \pm 13.7$ & $54.2 \pm 12.7$ & $51.8 \pm 13.5$ & $57.5 \pm 13.6$ \\
\hline $\begin{array}{l}\text { Characteristics of } \\
\text { placebo treatment }\end{array}$ & $\begin{array}{l}1 \text { tablet per day for up to } \\
12 \text { weeks }\end{array}$ & 1 tablet per day for 4 weeks & 1 tablet per day for 12 weeks & $\begin{array}{l}\text { 3-8 tablets per day for up to } \\
91 \text { days }\end{array}$ \\
\hline $\begin{array}{l}\text { Time to outcome } \\
\text { measure }\end{array}$ & $\begin{array}{l}0 \text { (baseline) }^{\dagger}, 1 \text { week, } \\
2 \text { weeks, } 4 \text { weeks and } \\
12 \text { weeks (or time of } \\
\text { withdrawal*) }^{\star}\end{array}$ & $\begin{array}{l}0 \text { (baseline) }^{\ddagger}, 1 \text { week, } \\
2 \text { weeks and } 4 \text { weeks } \\
\text { (or time of withdrawal*) }\end{array}$ & $\begin{array}{l}0 \text { (baseline) }^{\dagger}, 1 \text { week, } 2 \text { weeks, } 4 \text { weeks, } \\
8 \text { weeks and } 12 \text { weeks (or time of } \\
\text { withdrawal }^{\star} \text { ) }\end{array}$ & $\begin{array}{l}0 \text { (baseline) }^{\S} \text { and } 91 \text { days (or } \\
\text { time of withdrawal }{ }^{\star} \text { ) }\end{array}$ \\
\hline Pain outcomes & $\begin{array}{l}\text { VAS score }{ }^{\Uparrow} \text { of how much } \\
\text { pain in the previous week: } \\
76.9 \mathrm{~mm}^{\dagger}, 59.9 \mathrm{~mm} \text {, } \\
54.9 \mathrm{~mm}, \mathbf{5 1 . 9} \mathbf{~ m m} \text { and } \\
\mathbf{5 1 . 9} \mathrm{mm}\end{array}$ & $\begin{array}{l}\text { VAS score }{ }^{\Uparrow} \text { of how much pain } \\
\text { in the previous week: } \\
77.5 \mathrm{~mm}^{\ddagger}, 55 \mathrm{~mm}, \mathbf{4 8} \mathrm{mm} \\
\text { and } 47 \mathrm{~mm}\end{array}$ & $\begin{array}{l}\text { VAS score }{ }^{\text {I }} \text { of how much pain in the } \\
\text { previous week: } 75.2 \mathrm{~mm}^{\dagger}, 61.0 \mathrm{~mm} \text {, } \\
57.2 \mathrm{~mm}, \mathbf{5 3 . 4} \mathbf{~ m m}, \mathbf{5 2 . 2} \mathbf{~ m m} \text { and } \\
\mathbf{4 9 . 7} \mathbf{~ m m}\end{array}$ & 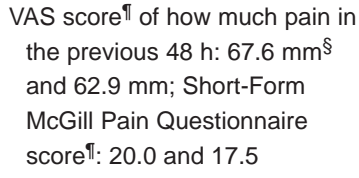 \\
\hline Disability outcomes & $\begin{array}{l}\text { RMDQ score }{ }^{\pi}: 14.1^{\dagger}, 11.1 \\
\text { 10.8, } 9.8 \text { and } 10.0\end{array}$ & $\begin{array}{l}\text { RMDQ score }^{\Uparrow}: 14.2^{\ddagger}, 11.1 \\
10.3 \text { and } \mathbf{9 . 2}\end{array}$ & $\begin{array}{l}\text { RMDQ scoreף: } 13.9^{\dagger}, 11.1,10.6,9.79,9.9 \\
\text { and } 9.79\end{array}$ & RMDQ score ${ }^{\Uparrow:}: 15.0^{\S}$ and 13.7 \\
\hline Other outcomes & & $\begin{array}{l}\text { Patient global assessment of } \\
\text { response to therapy }{ }^{\Uparrow * \star}, \% \\
\text { rating good or excellent: NA, } \\
\text { NR, NR and } 34 \%\end{array}$ & $\begin{array}{l}\text { Physician and patient overall assessment } \\
\text { of response to therapy }{ }^{\Uparrow \star \star}, \% \text { rating good } \\
\text { or excellent: NA, NR, NR, NR, NR and } \\
35-40 \%\end{array}$ & $\begin{array}{l}\text { Subjects reporting }>30 \% \text { pain } \\
\text { relief: NA and } \mathbf{2 0 . 7 \%}\end{array}$ \\
\hline
\end{tabular}

Bolded values represent a $30 \%$ or greater change from baseline. ${ }^{*}$ Intention-to-treat analysis - outcomes were assessed at the final visit before withdrawal; ${ }^{\dagger}$ Baseline measurements were taken following a four- to 15-day medication washout phase; ${ }^{\ddagger}$ Baseline measurements were taken following a three- to 10 -day medication washout phase; §Baseline measurements were taken following a three-week medication washout phase; "Values represent average scores; ${ }^{\star}{ }^{2}$ Response to therapy was rated as 0 = none, 1 = poor, 2 = fair, 3 = good and 4 = excellent. NA Not applicable; NR Not reported; RMDQ Roland Morris Disability Questionnaire; VAS Visual analogue scale

week of treatment, which then increased to $54 \%$ of subjects reporting this level of improvement by the end of four weeks. Unlike pain, average disability scores only showed significant improvements after four weeks of treatment. The second study that examined chronic LBP (29) did not find a significant improvement in pain based on pooled subject averages. However, $39.5 \%$ of the subjects did report a clinically meaningful improvement in their individual pain score at the conclusion of 91 days of treatment. Furthermore, $32.5 \%$ of subjects individually reporting a clinically meaningful improvement in their pain scores showed a greater than $50 \%$ improvement. Average disability scores reported in this study did not indicate any clinically significant improvements (29).

Qualitative analysis of 'just missed' studies

All four studies included in the present review as having 'just missed' being included as best-evidence trials used sham oral medication as a placebo intervention for subjects with chronic LBP (32-35). A summary of the results of these studies is given in Table 4. One study found significant improvements in subjects' average pain scores after two weeks of treatment (33) and two studies found significant improvements in subjects' average pain scores after four weeks of treatment $(32,34)$. Only one study (35) did not indicate a significant improvement in pain, based on pooled subject averages. However, $20.7 \%$ of subjects did report a greater than $30 \%$ improvement at the conclusion of 91 days of treatment. Two of the four 'just missed' studies $(32,33)$ found significant improvements in average disability scores after four weeks.

\section{DISCUSSION}

The aim of the present review was threefold: first, to determine whether one treatment resulted in a more profound change in LBP symptoms after a sham intervention than another; second, to determine whether any of those observed effects were large enough to be considered clinically meaningful; and finally, to assess whether studies designed specifically to assess the contribution of the true placebo effect were warranted. While the initial intention of the present review was to examine multiple, prespecified forms of LBP treatment, the range of treatments qualifying for review was quickly limited because many forms of commonly used treatment (eg, chiropractic and acupuncture) have yet to establish and/or make sufficient use of an appropriate structurally equivalent and inert placebo $(36,37)$. Furthermore, various electrotherapies were excluded because patients can experience a physical sensation during the application of most electrotherapeutic modalities. The difficulty in blinding subjects to placebo electrotherapy has been exemplified in a study by Deyo et al (38), in which multiple design features such as visually identical units, naive subjects, avoidance of a crossover design and use of identical visit frequency still only resulted in partial blinding success. Ultimately, ultrasound, laser and drug therapy were the only treatments found to meet the established criteria of the present review. Interestingly, however, very few LBP studies made use of ultrasound as a placebo, and none of those that did were admissible into our review. This was particularly surprising because sham or 'subtherapeutic' ultrasound has been suggested to be an effective placebo for use in LBP clinical trials (39). 
Despite unanimous agreement among reviewers with regard to most methodological issues that resulted in the exclusion of studies, there was some debate that centred around two main methodological issues. The studies of greatest debate were methodologically sound for their respective inherent purposes, but each allowed the continuation of co-interventions that may have affected the very outcome measures that were the focus of the review. Four studies (32-35) allowed subjects to continue receiving manual therapies (ie, physical therapy, massage and chiropractic care) if their use had been stable for one to three months before entering the study. Although such treatments would not be expected to influence comparison studies after proper randomization, they do have the potential to bias the outcomes of each group independently. Despite this, these studies were included in the review as papers that 'just missed' being best evidence for several reasons. First, they all dealt with chronic LBP, which has an unfavourable long-term prognosis. More importantly, all co-interventions had been consistently used by subjects for one to three months before entering the study and, thus, baseline measurements could be expected to reflect the therapeutic value of these co-interventions.

The second methodological issue causing debate was the use of blinding, particularly in trials that used a run-in phase as part of their study. A run-in phase design means that all subjects were given an active treatment for a set time period and were then moved into a placebo-controlled double-blinded phase. Outcomes were measured as a regression of the initial improvements made during the run-in phase. This was considered to be a possible hindrance for successful blinding because of the potential for withdrawal symptoms to be experienced by the participants, which could ultimately make them aware of their placebo group designation. The potential for such complications was accentuated by the fact that all of the 'run-in' studies examined opioid medications, which are well known for creating dependency in patients (40). Consequently, these studies were rejected for the present review.

Sham laser: The present review found conflicting evidence with regard to the changes in pain and disability scores after the use of sham laser for the treatment of LBP or related disability. While one study found that a significant proportion of subjects had a greater than $30 \%$ improvement in pain (24), the remaining two studies showed no effect. Further extrapolation from these results was also hindered by the relatively small sample size used by studies deemed to be of high quality and accepted into the present review. Consequently, no firm conclusions could be drawn with regard to pain. For disability scores, none of the accepted studies found clinically meaningful improvements. Generally speaking, only a small number of studies examined the treatment of LBP in conjunction with using a sham laser placebo and, from the studies retrieved, most were judged to be inadequate in terms of scientific validity.

Sham medication: The present best-evidence review indicated that there is a clinically meaningful, observable change in pain scores following the use of sham oral medications for the treatment of nonspecific LBP. Nine studies - all five of the best-evidence studies (27-31) and all four that 'just missed' this standard (32-35) - found a clinically significant improvement in average subjective, continuous pain scores after treatment when compared with baseline. Moreover, this improvement was reported in studies that examined acute, subacute and chronic LBP. In contrast, the effect of sham medications on disability was less favourable. Of the eight studies that examined disability, only five (28,30-33) found clinically meaningful improvements in subjective, continuous disability scores. Furthermore, because of the time course associated with this particular outcome measure, the possibility that the reductions in disability were simply a reflection of the natural history of the condition cannot be ruled out. Overall, the results suggest that the use of sham oral medications has a more pronounced effect on pain scores than disability scores. Unfortunately, based on the limited and heterogeneous nature of the data available in the present review, there is no indication of whether acute, subacute or chronic LBP would benefit most from the nonspecific effects associated with this sham intervention. In addition, due to the conflicting evidence found with regard to sham laser, a tangible comparison between sham laser and sham medication for the treatment of LBP is not possible; however, the results do suggest that the observed changes in pain associated with sham medication are more pronounced.

A noteworthy weakness of the present review was the inclusion of studies that lacked no-treatment control groups; thus, outcomes had to be based on comparisons with baseline measures. Indeed, patients who improved after receiving a placebo control may have improved as a result of the natural history of the disorder (41). Although it is irrefutable that the outcomes discussed herein represent an observed placebo response as opposed to a true placebo effect, it is difficult to differentiate the contribution of natural history (42). However, prognostic studies evaluating the natural progression of LBP are numerous and may be used as substitutes for the no-treatment control groups that are lacking in the included studies. In the present review, both studies concerning acute $\operatorname{LBP}(27,28)$ found an average improvement of $30 \%$ to $42 \%$ in VAS pain scores after only three days of treatment with sham medications, whereas natural history predicts that $25 \%$ to $30 \%$ of patients will improve in seven days (9). Even so, it remains difficult to conclude whether these improvements are due to natural progression of the condition.

More convincing evidence of the therapeutic relevance of sham medication may be provided from studies evaluating the treatment of chronic LBP. Four of the six chronic LBP studies reported in the present review found clinically meaningful improvements in average VAS pain scores after two to four weeks of treatment $(30,32-34)$ and those that did not report such improvements in average pain scores reported meaningful improvements in a significant number of individual subjects $(29,35)$. Moreover, the $30 \%$ improvement in average pain scores occurred in $40 \%$ to $54 \%$ of subjects who, at baseline, had reported daily analgesic use for up to 11 years $(29,30)$. In fact, one study (30) reported a greater than 50\% improvement in nearly one-half of the subjects after one week. Finally, several studies monitored subjects for as many as eight to 13 weeks $(29,32,34,35)$, thus decreasing the likelihood that reported improvements are a convenient but temporary natural lull in symptoms.

Another common criticism of using baseline comparisons to evaluate clinical efficacy of placebo treatments is the inability to account for regression to the mean (4). In general, when observing repeated measurements in the same subject, relatively high observations of the outcome measure(s) are likely to be followed by less extreme ones at the next observation, with the latter being nearer to the subject's true mean (43). All but two $(27,34)$ of the oral medication studies included in the present review used baseline VAS pain scores of $40 \mathrm{~mm}$ or higher as an inclusion criterion. Thus, their subject populations are representative of an extreme subgroup and this has been suggested to increase the potential for regression to the mean (43). However, recent prognostic studies have indicated that higher LBP intensity at baseline is, in fact, associated with a poorer prognosis (13). Although it is impossible to quantify what the contribution of regression to the mean may have been, it is possible that using subjects with more intense LBP at baseline may have reduced the impact of this statistical phenomenon.

It has been suggested that a treatment must have meaning to the patient before an effective placebo effect can be expected (1). It follows then that there is likely a subgroup of patients who would benefit more than others from the use of a particular placebo treatment. Indeed, when the average and individual changes in pain scores are compared, several studies presented in the present review do suggest that subgroups of patients are benefitting (29,30,35). Moreover, because other studies presented herein demonstrate only average changes in pain scores, it must be considered that, similarly, some of these patients are improving to a greater extent and others perhaps not at all. Regardless of the variability in improvements experienced by different patient subgroups, it has been shown that the effect of placebo analgesia can be greater when patients are told that a placebo treatment is actually a painkiller, compared with when they are 
told that they may receive either a painkiller or placebo $(17,41)$. If these findings generalize to conditions that underlie LBP, then the changes in pain and disability scores in these double-blinded placebocontrolled trials are likely to be reduced compared with the use of placebo treatment in clinical practice.

Because the side effects of treatment with a sham medication would be limited to those that are psychosomatic, perhaps it is appropriate that placebo treatments be used initially to determine whether a patient will respond positively, rather than immediately prescribing higher risk medications such as opioids and nonsteroidal anti-inflammatory

\section{REFERENCES}

1. Moerman DE, Jonas WB. Deconstructing the placebo effect and finding the meaning response. Ann Intern Med 2002;136:471-6.

2. Beecher HK. The powerful placebo. JAMA 1955;159:1602-6.

3. Miller FG, Colloca L. The legitimacy of placebo treatments in clinical practice: Evidence and ethics. Am J Bioethics 2009;9:39-47.

4. Hrobjartsson A, Gotzsche P. Is the placebo powerless? An analysis of clinical trials comparing placebo with no treatment. N Engl J Med 2001;344:1594-602.

5. Cook TD, Leviton LC. Reviewing the literature: A comparison of traditional methods with meta-analysis. J Pers 1980;48:449-72.

6. Kirsch I, Scoboria A. Apples, oranges, and placebos: Heterogeneity in a meta-analysis of placebo effects. Adv Mind Body Med 2001;17:307-9.

7. Tilburt JC, Emanuel EJ, Kaptchuk TJ, Curlin FA, Miller FG. Prescribing "placebo treatments": Results of national survey of US internists and rheumatologists. Br Med J 2008;337:a1938.

8. Walker BF. The prevalence of low back pain: A systematic review of the literature from 1966 to 1998. J Spinal Disord 2000;13:205-17.

9. Deyo RA, Weinstein JN. Low back pain. N Engl J Med 2001;344:363-70.

10. Coste J, Delecoeuillerie G, Cohen de Lara A, Le Parc JM, Paolaggi JB. Clinical course and prognostic factors in acute low back pain: An inception cohort study in primary care practice. Br Med J 1994;308:577-80.

11. Cherkin DC, Deyo RA, Street JH, Barlow W. Predicting poor outcomes for back pain seen in primary care using patients' own criteria. Spine 1996;21:2900-7.

12. Croft PR, Macfarlane GJ, Papageorgiou AC, Thomas E, Silman AJ. Outcome of low back pain in general practice: A prospective study. Br Med J 1998;316:1356-9.

13. Henschke N, Maher CG, Refshauge KM, et al. Prognosis in patients with recent onset low back pain in Australian primary care: Inception cohort study. Br Med J 2008;337:a171.

14. Hestbaek L, Leboeuf-Yde C, Manniche C. Low back pain: What is the long-term course? A review of studies of general patient populations. Eur Spine J 2003;12:149-65.

15. Hestbaek L, Leboeuf-Yde C, Engberg M, Lauritzen T, Bruun NH, Manniche C. The course of low back pain in a general population. Results from a 5-year prospective study. J Manip Physiol Ther 2003;26:213-9.

16. Guzmán J, Esmail R, Karjalainen K, Malmivaara A, Irvin E, Bombardier C. Multidisciplinary rehabilitation for chronic low back pain: Systematic review. Br Med J 2001;322:1511-6.

17. Pollo A, Amanzio M, Arslanian A, Casadio C, Maggi G, Benedetti F. Response expectancies in placebo analgesia and their clinical relevance. Pain 2001;93:77-84.

18. Amanzio M, Pollo A, Maggi G, Benedetti F. Response variability to analgesics: A role for non-specific activation of endogenous opioids. Pain 2001;90:205-15.

19. Van Tulder M, Furlan A, Bombardier C, Bouter L. Updated method guidelines for systematic reviews in the Cochrane Collaboration Back Review Group. Spine 2003;28:1290-9.

20. Carroll LJ, Cassidy JD, Peloso PM, et al. Methods for the best evidence synthesis on neck pain and its associated disorders: The Bone and Joint Decade 2000-2010 Task Force on Neck Pain and Its Associated Disorders. Spine 2008;33:S33-S38.

21. Moher D, Schulz KF, Altman D. The CONSORT statement: Revised recommendations for improving the quality of reports of parallel-group randomized trials. JAMA 2001;285:1987-91.

22. Slavin RE. Best evidence synthesis: An intelligent alternative to meta-analysis. J Clin Epidemiol 1995;48:9-18. drugs $(44,45)$. As such, the prescription of some form of placebo therapy by approximately one-half of internists and rheumatologists for their patients (7) may be justified in the treatment of LBP, and the use of sham medication may be a viable first choice. Although the evidence presented in the present review is insufficient to justify the use of sham medications for the treatment of LBP in clinical practice, this study does suggest that further analysis is warranted to identify which patient subgroups could benefit most from such treatment and distinguish the true contribution of the placebo effect by conducting studies comparing sham medication with no-treatment controls.

23. Ostelo RW, Deyo RA, Stratford P, et al. Interpreting change scores for pain and functional status in low back pain: Towards international consensus regarding minimal important change. Spine 2008;33:90-4.

24. Soriano F, Rios R. Gallium arsenide laser treatment of chronic low back pain: A prospective, randomized and double blind study. Laser Ther 1998;10:175-80.

25. Basford JR, Shefield CG, Harmsen WS. Laser therapy: A randomized, controlled trial of the effects of low-intensity Nd:YAG laser irradiation on musculoskeletal back pain. Arch Phys Med Rehabil 1999;80:647-52.

26. Preyde M. Effectiveness of massage therapy for subacute low-back pain: A randomized controlled trial. Can Med Assoc J 2000;162:1815-20.

27. Amlie E, Weber H, Holme I. Treatment of acute low-back pain with piroxicam: Results of a double-blind placebo-controlled trial. Spine 1987;12:473-6.

28. Dreiser RL, Marty M, Ionescu E, Gold M, Liu JH. Relief of acute low back pain with diclofenac-k $12.5 \mathrm{mg}$ tablets: A flexible dose, ibuprofen $200 \mathrm{mg}$ and placebo-controlled clinical trial. Int J Clin Pharmacol Ther 2003;41:375-85.

29. Ruoff GE, Rosenthal N, Jordan D, Karim R, Kamin M. Tramadol/acetaminophen combination tablets for the treatment of chronic lower back pain: A multicenter, randomized, double-blind, placebo-controlled outpatient study. Clin Ther 2003;25:1123-41.

30. Coats TL, Borenstein DG, Nangia NK, Brown MT. Effects of valdecoxib in the treatment of chronic low back pain: Results of a randomized, placebo-controlled trial. Clin Ther 2004;26:1249-60.

31. Bannwarth B, Allaert FA, Avouac B, Rossignol M, Rozenberg S, Valat JP. A randomized, double-blind, placebo controlled study of oral adenosine triphosphate in subacute low back pain. J Rheumatol 2005;32:1114-7.

32. Birbara CA, Puopolo AD, Munoz DR, et al. Treatment of chronic low back pain with etoricoxib, a new cyclo-oxygenase-2 selective inhibitor: Improvement in pain and disability - a randomized, placebo-controlled, 3-month trial. J Pain 2003;4:307-15.

33. Katz N, Ju WD, Krupa DA, et al. Efficacy and safety of rofecoxib in patients with chronic low back pain: Results from two 4-week, randomized, placebo-controlled, parallel-group, double-blind trials. Spine 2003;28:851-8.

34. Pallay RM, Seger W, Adler JL, et al. Etoricoxib reduced pain and disability and improved quality of life in patients with chronic low back pain: A 3 month, randomized, controlled trial. Scand J Rheumatol 2004:33:257-66.

35. Peloso PM, Fortin L, Beaulieu A, Kamin M, Rosenthal N. Analgesic efficacy and safety of tramadol/ acetaminophen combination tablets (ultracet) in treatment of chronic low back pain: A multicenter, outpatient, randomized, double blind, placebo controlled trial. J Rheumatol 2004;31:2454-63.

36. Lundeberg T, Lund I, Sing A, Näslund J. Is placebo acupuncture what it is intended to be? Evid Based Complement Alternat Med 2009. (In press)

37. Hancock MJ, Maher CG, Latimer J, McAuley JH. Selecting an appropriate placebo for a trial of spinal manipulative therapy. Aust J Physiother 2006;52:135-8.

38. Deyo RA, Walsh NE, Schoenfeld LS, Ramamurthy S. Can trials of physical treatments be blinded? The example of transcutaneous electrical nerve stimulation for chronic pain. Am J Phys Med Rehabil 1990;69:6-10. 
39. Fulda KG, Slicho T, Stoll ST. Patient expectations for placebo treatments commonly used in osteopathic manipulative treatment (OMT) clinical trials: A pilot study. Osteopath Med Prim Care 2007;1:3.

40. Reid MC, Engles-Horton LL, Weber MB, Kerns RD, Rogers EL, O'Connor PG. Use of opioid medications for chronic noncancer pain syndromes in primary care. J Gen Intern Med 2002;17:173-9.

41. Vase L, Riley JL, Price DD. A comparison of placebo effects in clinical analgesic trials versus studies of placebo analgesia. Pain 2002;99:443-52.

42. Millera FG, Rosenstein DL. Variance and dissent: The nature and power of the placebo effect. J Clin Epidemiol 2006;59:331-5.

43. Barnett AG, van der Pols JC, Dobson AJ. Regression to the mean: What it is and how to deal with it. Int J Epidemiol 2005;34:215-20.

44. Manchikanti KN, Manchikanti L, Damron KS, Pampati V, Fellows B. Increasing deaths from opioid analgesics in the United States: An evaluation in an interventional pain management practice. J Opioid Manag 2008;4:271-83.

45. Tramèr MR, Moore RA, Reynolds DJ, McQuay HJ. Quantitative estimation of rare adverse events which follow a biological progression: A new model applied to chronic NSAID use. Pain 2000;85:169-82.

46. Berry H, Bloom B, Hamilton EB, Swinson DR. Naproxen sodium, diflunisal, and placebo in the treatment of chronic back pain. Ann Rheum Dis 1982;41:129-32.

47. Schnebel BE, Simmons JW. The use of oral colchicine for low-back pain. A double-blind study. Spine 1988;13:354-7.

48. Berry H, Hutchinson DR. A multicentre placebo-controlled study in general practice to evaluate the efficacy and safety of tizanidine in acute low-back pain. J Int Med Res 1988;16:75-82.

49. Toya S, Motegi M, Inomata K, Ohshiro T, Maeda T. Report on a computer-randomized double blind clinical trial to determine the effectiveness of the GaAlAs ( $830 \mathrm{~nm}$ ) diode laser for pain attenuation in selected pain groups. Laser Ther 1994;6:143-8.

50. Atkinson JH, Slater MA, Williams RA, et al. A placebo-controlled randomized clinical trial of nortriptyline for chronic low back pain. Pain 1998;76:287-96.

51. Chrubasik S, Junck H, Breitschwerdt H, Conradt C, Zappe H. Effectiveness of harpagophytum extract WS 1531 in the treatment of exacerbation of low back pain: A randomized, placebocontrolled, double-blind study. Eur J Anaesthesiol 1999;16:118-29.

52. Chrubasik S, Eisenberg E, Balan E, Weinberger T, Luzzati R, Conradt C. Treatment of low back pain exacerbations with willow bark extract: A randomized double-blind study. Am J Med 2000;109:9-14.

53. Dickens C, Jayson M, Sutton C, Creed F. The relationship between pain and depression in a trial using paroxetine in sufferers of chronic low back pain. Psychosomatics 2000;41:490-9.

54. Katz J, Pennella-Vaughan J, Hetzel RD, Kanazi GE, Dworkin RH. A randomized, placebo-controlled trial of bupropion sustained release in chronic low back pain. J Pain 2005;6:656-61.

55. Muehlbacher M, Nickel MK, Kettler C, et al. Topiramate in treatment of patients with chronic low back pain: A randomized, double-blind, placebo-controlled study. Clin J Pain 2006;22:526-31.

56. Vondrackova D, Leyendecker P, Meissner W, et al. Analgesic efficacy and safety of oxycodone in combination with naloxone as prolonged release tablets in patients with moderate to severe chronic pain. J Pain 2008;9:1144-54.

57. Basmajian JV. Acute back pain and spasm. A controlled multicenter trial of combined analgesic and antispasm agents. Spine 1989;14:438-9.

58. Snyder-Mackler L, Barry AJ, Perkins AI, Soucek MD. Effects of helium-neon laser irradiation on skin resistance and pain in patients with trigger points in the neck or back. Phys Ther 1989;69:336-41.

59. Klein RG, Eek BC. Low-energy laser treatment and exercise for chronic low back pain: Double-blind controlled trial. Arch Phys Med Rehabil 1990;71:34-7.

60. Hoiriis KT, Pfleger B, McDuffie FC, et al. A randomized clinical trial comparing chiropractic adjustments to muscle relaxants for subacute low back pain. J Manip Physiol Ther 2004;27:388-98.

61. Goodkin K, Gullion CM, Agras WS. A randomized, double-blind, placebo-controlled trial of trazodone hydrochloride in chronic low back pain syndrome. J Clin Psychopharmacol 1990;10:269-78.

62. Szpalski M, Hayez JP. Objective functional assessment of the efficacy of tenoxicam in the treatment of acute low back pain. A double-blind placebo-controlled study. Br J Rheumatol 1994;33:74-8.

63. Ketenci A, Ozcan E, Karamursel S. Assessment of efficacy and psychomotor performances of thiocolchicoside and tizanidine in patients with acute low back pain. Int J Clin Pract 2005;59:764-70.

64. Gale GD, Rothbart PJ, Li Y. Infrared therapy for chronic low back pain: A randomized, controlled trial. Pain Res Manage 2006;11:193-6.

65. Webster LR, Butera PG, Moran LV, Wu N, Burns LH, Friedmann N. Oxytrex minimizes physical dependence while providing effective analgesia: A randomized controlled trial in low back pain. J Pain 2006;7:937-46.

66. Vorsanger GJ, Xiang J, Gana TJ, Pascual ML, Fleming RR. Extended-release tramadol (tramadol ER) in the treatment of chronic low back pain. J Opioid Manag 2008;4:87-97.

67. Schnitzer TJ, Gray WL, Paster RZ, Kamin M. Efficacy of tramadol in treatment of chronic low back pain. J Rheumatol 2000;27:772-8.

68. Ansari NN, Ebadi S, Talebian S, et al. A randomized, single blind placebo controlled clinical trial on the effect of continuous ultrasound on low back pain. Electromyogr Clin Neurophysiol 2006;46:329-36.

69. Hale ME, Ahdieh H, Ma T, Rauck R. Efficacy and safety of opana ER (oxymorphone extended release) for relief of moderate to severe chronic low back pain in opioid-experienced patients: A 12-week, randomized, double-blind, placebo-controlled study. J Pain 2007;8:175-84.

70. Katz N, Rauck R, Ahdieh H, et al. A 12-week, randomized, placebo-controlled trial assessing the safety and efficacy of oxymorphone extended release for opioid-naive patients with chronic low back pain. Curr Med Res Opin 2007;23:117-28.

71. Faas A, Chavannes AW, Van Eijk JTM, Gubbels JW. A randomized, placebo-controlled trial of exercise therapy in patients with acute low back pain. Spine 1993;18:1388-95.

72. Dapas F, Hartman SF, Martinez L, et al. Baclofen for the treatment of acute low-back syndrome. A double-blind comparison with placebo. Spine 1985;10:345-9.

73. Alcoff J, Jones E, Rust P, Newman R. Controlled trial of imipramine for chronic low back pain. J Fam Pract 1982;14:841-6. 


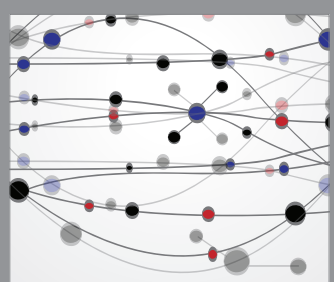

The Scientific World Journal
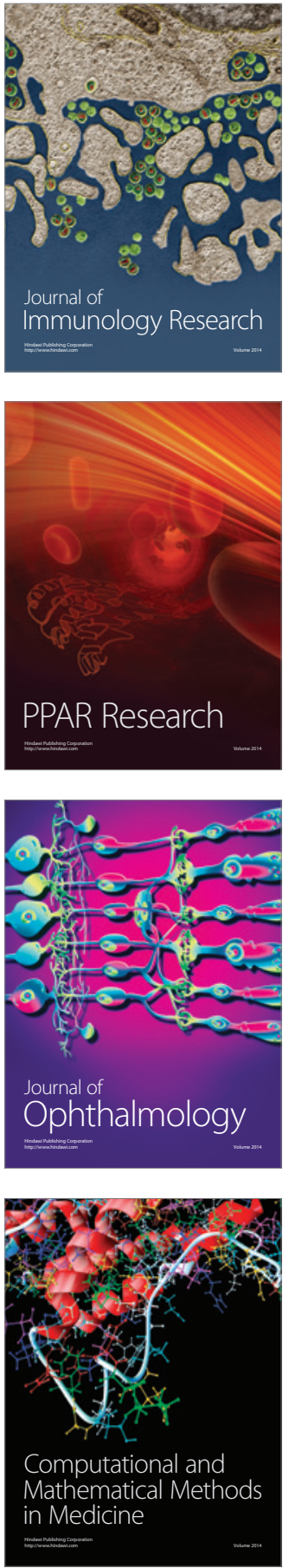

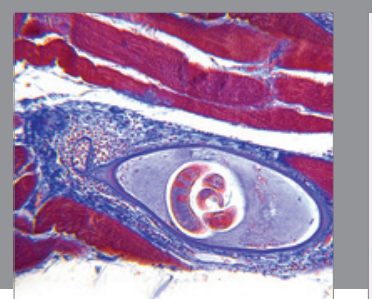

Gastroenterology Research and Practice

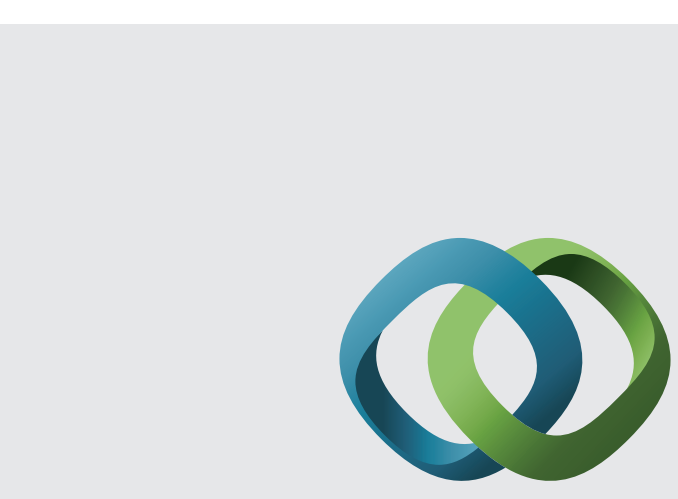

\section{Hindawi}

Submit your manuscripts at

http://www.hindawi.com
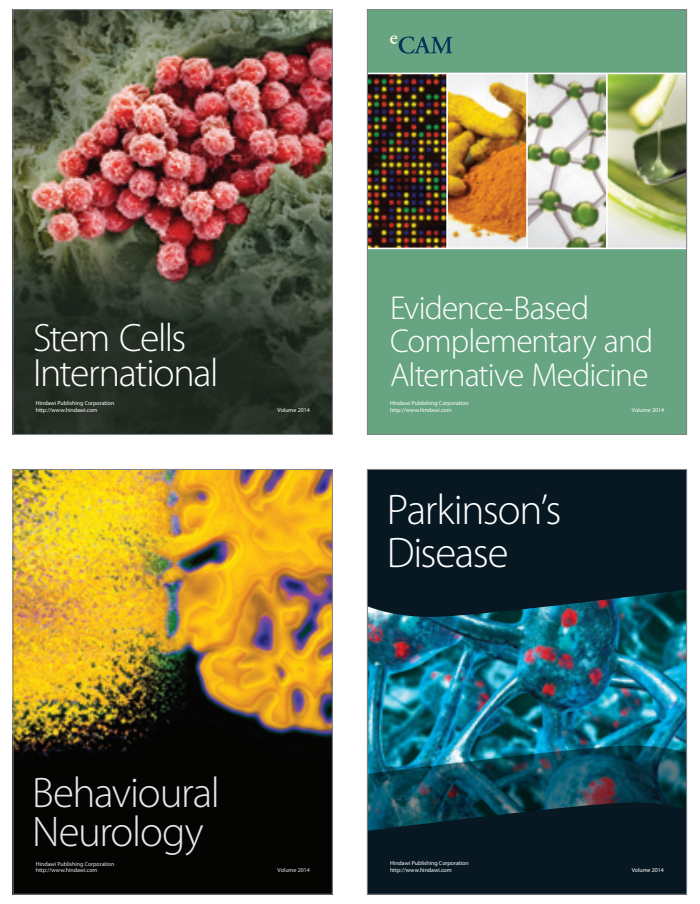
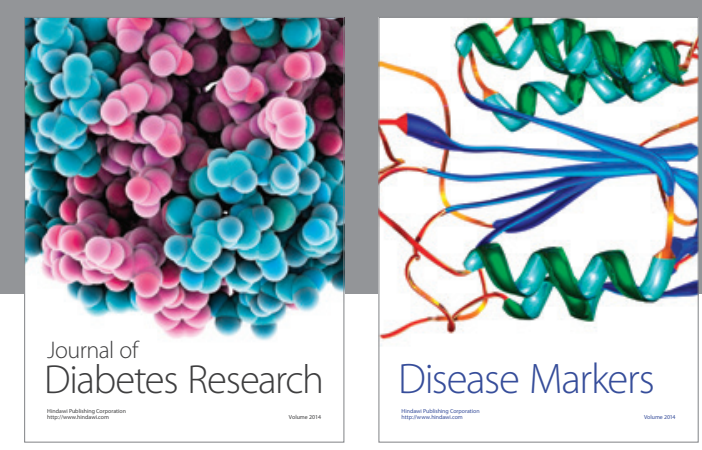

Disease Markers
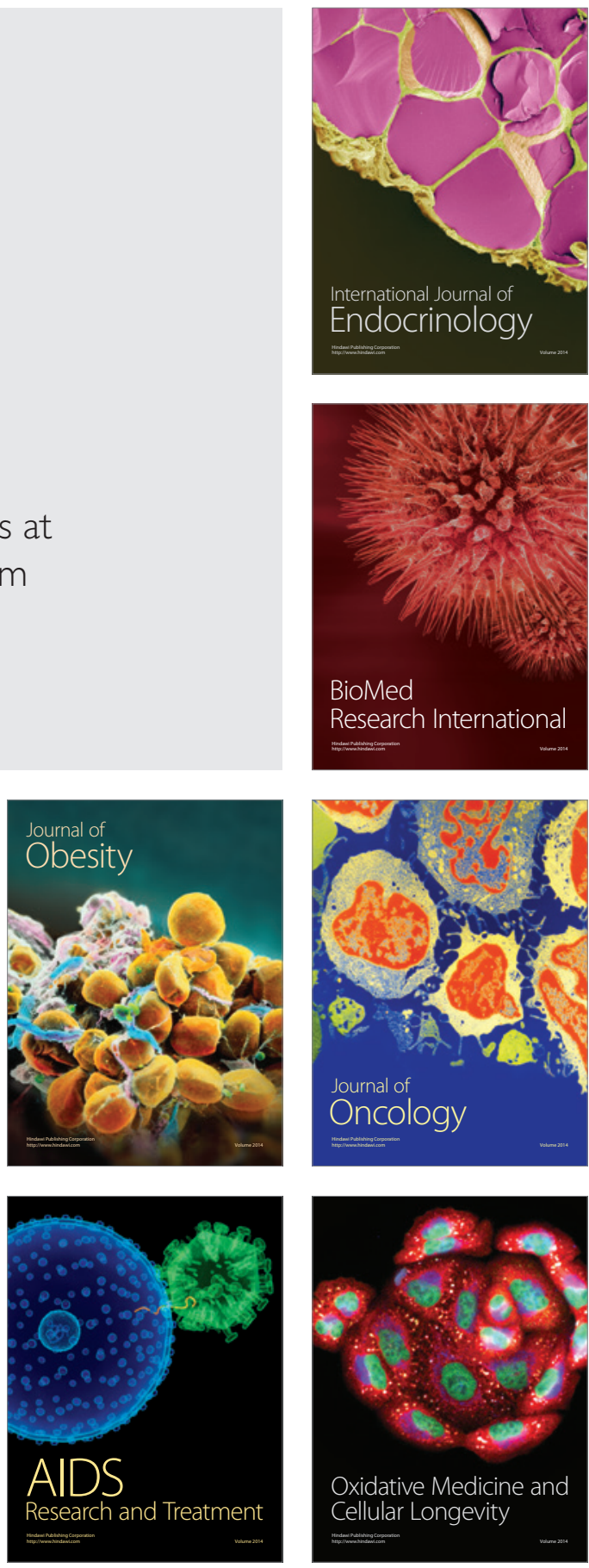